\title{
Michał Kapias
}

University of Economics in Katowice

Faculty of Economics

Department of Public Management and Social Sciences

e-mail: michal.kapias@ue.katowice.pl

\section{Grzegorz Polok}

University of Economics in Katowice

Faculty of Economics

Department of Public Management and Social Sciences

e-mail: grzegorz.polok@ue.katowice.pl

\section{The role of ethics in the educational process implemented in the university space"}

\begin{abstract}
Global changes around the world have demanded various transformations, including in the area of higher education. The aim of academic education is no longer to prepare people to work in particular occupations, but to create the appropriate abilities which are useful in the labor market. This kind of education must embody a multi-aspect character, because it prepares people for life-long learning. Therefore, when creating a "learning society", one should make an effort to think of axiological dimension of scientific-technical advance. One ought to take into account the human elements of education, especially ethical issues. Practice shows that human relationships bereft of a transcendent and ethical dimension, and which focus only on financial, economic goods, on profit, the market and competition, do not bring anyone happiness. Hence there is an enormous demand in the academic community for ethical reflection, thanks to which, man is not only improved in the anthropological dimension, but also in the socio-economic aspect.
\end{abstract}

Keywords: education, upbringing, academic community

JEL Classification: A20, Z1

\footnotetext{
${ }^{*}$ The article is an updated version of the paper published in Polish in the Annales. Ethics in Economic Life, 15(1), 193-203.
} 


\section{Introduction}

Globalization processes, which have been taking place in the world for many years, have an enormous influence on a number of areas, including human socio-economic activity. The activities carried out in this domain make it essential to facilitate the transfer of individual jobs on a global scale, which is not without significance for minimizing operating costs in the context of the location of employment. This situation is, in a way, motivated by the technological changes that have occurred rapidly in recent years. As a result, it is difficult to predict - even at short time intervalsthe effects of such sudden and radical transformations, not only for the retail and services market but also for the labor market. Such tendencies mean that the higher education that people obtain no longer guarantees professional success nor the possibility to maintain the same employment throughout life. Even highly specialized professionals can be temporarily unemployed because their qualifications are too narrow-technologies, services and market requirements all change, which also creates new needs, including in the labor market.

Such rapid changes also force innovative solutions in the field of education, in particular, at higher levels. It turns out that higher education still makes it possible to achieve a professional career, but it does not guarantee professional qualifications that would allow people to work in accordance with their field of study. The purpose of academic education is no longer to prepare people to practice a particular profession, but rather to provide knowledge and to develop relevant skills useful in the process of changing requirements on the labor market. Such an education, in its essence, must have a general, multi-faceted character, because it prepares people for lifelong learning.

Therefore, the basic objective of the operation of universities is not only to develop research, but above all to educate people of various levels who are able to create and develop the economic potential of regions and countries (Moratis, Hoff \& Reul, 2006). For this reason, universities are given particularly high requirements due to the role they play in the socio-economic development of the state. It is in the academic environment that the diffusion of knowledge takes place, as well as the shaping of the structure of values respected by the future elites (Sobczak, Debucquet \& Havard, 2006). Therefore, the changes should aim at preparing graduates for the needs of the labor market, developing and maintaining advanced knowledge bases, shaping active civic attitudes, as well as fostering the personal development of students. Unfortunately, this category is placed at the very end, which often means that it is ignored and skipped (Kapias, 2009, p. 125).

\section{The European Union and academic education}

Considering the facts indicated in the introduction to this article, the European Union has created a strategy in which, by transforming its knowledge-based economy, it emphasizes the importance of increasing expenditures on education as 
a factor in increasing the innovativeness of the economy (Adamczyk, 2009, pp. 38-53). This course of action is a consequence of the observation that the process of learning, transferring knowledge, sharing it and creating innovation is conditioned by the cooperation and trust created in the regional environment. Therefore, there is a need to strengthen the role of higher education. Such tendencies can also be found in the EU document entitled White Paper on Education and Training. Teaching and Learning_-Towards the Learning Society (1995).

Due to increasing unemployment, serious socio-economic and political problems arise (European Community, 1995, p. 2). Such a tendency is perceived as a waste of human capital, which is a considerable burden on the budget of each country. To remedy this, EU guidelines suggest that measures for education and improving professional qualifications should be strengthened, which will allow easier access to employment. It is also assumed that proper education is the driving force of development and effective international competition. An educated individual should be autonomous, critical, morally and socially responsible, and at the same time open to culture. In this context, the idea of a person created as a utilitarian tool used in the economy disappears (1995, p. 26). Hence, all kinds of investments in people are born, which need to be treated on a par with material investments. As a result, the emphasis is placed on education with a broad profile, which should be based on cultural, literary, but also philosophical and ethical knowledge.

Literature and philosophy fulfill the same function in respect to the indiscriminate bombardment of information from the mass media and, in the near future, from the large informatics networks. They arm the individual with powers of discernment and a critical sense. This can provide the best protection against manipulation, enabling people to interpret and understand the information they receive. Recalling and understanding the past is essential in order to judge the present. Knowledge of history (including scientific and technological history) and geography has a dual function as a guide in time and space which is essential to everyone if they are to come to terms with their roots, develop a sense of belonging and to understand others. (1995, p. 28)

As is clear from these words - the humanistic base should become the foundation of education.

Therefore, when creating a "learning society", the principle of subsidiarity should be applied, which necessitates the harmonization of all participants in the process, starting with the family, through schools or enterprises, and ending with local, regional and national public and even European authorities. By emphasizing the axiological dimension of scientific and technical progress and socio-economic development, without their unnecessary absolutization, they can be treated as tools in the development of an integral and personal vision of the human being. That is why "[...] educating and developing scientists should not be any different in the ethics of responsibility" (European Community, 1995, p. 25). In this context, it should be assumed that it is the university which shapes the potential of future 
highly qualified employees, and that it should focus on to the contents of curricula in relation to ethical issues (Wójcicka, 2007, pp. 41-56). Therefore, we should turn to the humanizing elements of education.

\section{Teaching in higher education as humanizing activities}

In the modern world, education aimed at creating a professional has become extremely desirable. However, the teaching process is not like physically modeling some material. It refers to a living human being. For this reason, the reemphasizing of activities aimed at imbuing the human individual with only certain skills to perform a specific action makes them an excellent multitasking machine, but at the same time, it deprives them of the possibility to pursue and develop their humanity. At the level of higher education, the training of professionals, even in terms of multitasking, is often carried out in such a way that the fundamental goal of education, which is the intellectual and personal development of a person, is neglected in its essence. Therefore, it is necessary to include in the didactic and educational process a certain amount of general and universal education, aimed at teaching young people creative and precise thinking, and a global vision of reality, thanks to which they will be able to solve difficult problems on their own and do well in intellectually demanding situations.

Therefore, it is necessary to introduce basic (universal) studies to the obligatory process of studying (Anzenbacher, 1992, pp. 40-41), which are the basis for scientific development and progress, from which the various sciences that underlie professional knowledge grow. Philosophy is a unique example of these studies, since, like most general knowledge, it is the basis of all other scientific knowledge (Jaroszyński, 1992, pp. 5-10) and must be at the source of education in any type of higher education. It allows us to see distant horizons, and perceive something more than current research structures, statistics, or the effectiveness of calculations. It asks questions about purposefulness, that is, the sense of task realization. Without such reflection it is easy to subject a young man-often living in his idealized world, a naïve man-to multiple, overwhelming manipulations. The practical usefulness of science is important, but it is the humanistic education that gives the student that individual sovereignty, making him independent of all the enslavements and pressures that modern man is subjected to. Negligence in the field of general intellectual erudition must ultimately result in the barbarism of the society.

As a result, there is an appeal to introduce obligatory ethical education into the plans of academic teaching. The purpose of this field of study is to know the truth about how to become a good person. There is a need to properly shape conscience and moral actions under the influence of various ethical reflectionsboth at the level of humanity, as well as in specialized business, economic and professional fields. All of us are involved in moral dilemmas, so they cannot be avoided, ignored, or completely silenced. Practice shows that interpersonal rela- 
tionships which are devoid of a transcendent and ethical dimension, focused instead solely on financial, economic goods, on profit, the market and competition, are cold, ruthless, and do not bring anyone happiness.

Looking at the contemporary world, it must be noted that there are not only political, economic, social or cultural phenomena in it, but the rigid and clear boundary between technology and nature, morality and law, is becoming blurred if not a fiction. These phenomena, which are so diverse in character, are closely related and interact with each other. That is why multiple problems or crises may be solved by specialists from various disciplines cooperating with each other. For this to happen, however, a mutual openness based on the universality of knowledge contained in education is needed. Openness exists only where a person is aware of it and wants to build it, thus facing other people. The ethical foundation of such an attitude should underlie all activities - both scientific and didactic. Ethical relativism, or even the lack of any reference to morality, poses a threat not only to science but, above all, to the whole of humankind.

\section{Ethics or the fulfillment of a moral obligation}

At every conscious stage of his development, man asks himself how to live. In particular, this question arises during the time of higher education because this is when many young people face existential dilemmas and, at the same time, it is the time of the most comprehensive development of their world view (Jaskot \& $\mathrm{Mu}-$ rawska, 2006). The question of morality emerging in this context makes us understand it as "the actual behavior of a person - their actions, attitudes, nourished views, and all this in the context of the good of man" (Gałkowski, 2002, p. 16). At the same time, it can be added that "morality itself is life and the domain of life, it is connected with human action. The author of morality is, therefore, man through his action" (Wojtyła, 1995, p. 13). It is not connected only with some fragment of human actions, but it covers the entire life of every individual-it is emphasized in the social, political, cultural or economic area. This entirety of human action in relation to the attainment of the good of every human being is subjected to scientific analysis. You can examine it from a historical, social, psychological or even logical point of view. However, ethics has a specific approach which examines human life and action from a moral point of view in a normative manner.

The mystery of ethics manifests itself in the concept of I should, which, above all, is astonishing. The actual meaning of this statement is enormous. First of all, it should be noted that it refers directly to man, to himself, captured as a subject of both cognition and action. It indicates that you are "someone" and not "something"- things should not do anything, or rather-they do not have to do anything. They are just there and only man with his "I" is aware of his own existence, and that he can do something, that he knows and decides. Through doing various acts, he makes choices, and it is ethics that tells you what to choose to make it good. While living, man learns and then fulfils his desires. However, only 
by discovering the truth does he feel in himself that mysterious I should; wanting to live righteously, achieve good, I should make such a choice that my actions should go in the direction of good, that they should be moral. Otherwise, man goes against himself, learning the truth that he recognized and accepted (but never created). So "I want" goes together with "I know". Therefore, ethics can be defined as "a philosophical science that establishes the moral foundations and rules of human action with the help of innate cognitive abilities" (Ślipko, 1974, p. 17). It is rational cognition and a justification of the value and duty of human activity resulting from being a human being. It is essentially theoretical knowledge, but fundamental to human existence. It is not only because of knowledge that man is good, but he becomes so when he knows good, chooses it and makes it happen.

However, the fundamental question remains: how does one recognize true good and how does one find the strength to choose and implement it? In other words: what and why should I? Is the best solution not given by personalism, which, when asked about what should I, indicates the figure of the human perceived as a person? At the starting point, there is a protest against all forms of human "reification". At the top of the hierarchy of beings there is a personal being, which, unlike things, is characterized by spirituality, autonomy, the ability to free self-determination, the possibility of expressing oneself in one's deeds and also one's works. First of all, personalism expresses the ethical conviction that a human act is morally good when it is an act of affirming a person for himself. This happens when this act takes into account the well-being of the person, his inborn and inalienable dignity (Styczeń, 1993, pp. 13-21; 1983, pp. 21-23). In turn, this dignity should be understood as the individual value of a person, which distinguishes him from other beings not only in the descriptive sense but also in the axiological sense. One can call it humanity, because it will be distinguished by those features that indicate that a person is a person, i.e., the ability to understand oneself, a sense of identity, pursuit of goals and life plans, freedom of selfmanagement, self-determination and reference to others (Dylus, 1984).

The personalistic norm has its foundation in insight into oneself. It formulates the basic duty of man towards man-discovering the truth about himself as a person, he also discovers it in another person, and realizes that in accepting this truth, the duty of unconditional love of each person appears (Wojtyła, 1986, 1994). The personalistic norm points to the source of the special value of man, because it emphasizes what distinguishes man from the natural world.

\section{Education as a personification process}

To educate in a personalistic way does not mean to shape or even train particular human individuals according to some original or ideological assumptions. Rather, it is about help (support), and about providing a kind of assistance to a person being brought up, understood as "forming a human or rather managing the 
dynamic development, through which a person shapes himself in order to be a human" (Maritain, 1949, p. 18), that is, a person fully. In other words, the educator does not model the person, but creates the best conditions for his development. However, development, as well as improvement, must be the fruit of his own efforts. This is mainly due to their autonomous character and their ontological structure. This is because a person is not perfect by "taking", but by "giving". This perfection is the ability to choose good, and also to co-create and persist in it. One can say that it is about a love for good and the ability to share it with others. This ability cannot be obtained from the outside; it needs to be developed in the self. And this is an ability which serves the educational process. Such behavior cannot be accomplished without the personal commitment of an educator who will not only point to the path leading to good, but he will, above all, walk it. In other words, it is a testimony of one's own life, which is to stimulate other people to imitate, to co-create a moral good in every person's life.

Personalistic education becomes a service for human development. When the value of personal dignity is emphasized, man learns to "be" more than to "have", and thus he understands his own life as a co-establishment with others, not a joint possession. At most, we can talk about joint possessing love by sharing it with others. However, it is necessary here to properly recognize the dignity of each person, so that in love they will not make it subject to themselves; not to objectify it, but to always constitute a fundamental subjective value. Love consists of doing good towards the person; it is directed at others. In its essence, it is focused on kindness and respect. Dignity becomes the fundamental value of personalistic education, where each person can discover and fully realize themselves.

The path of education thus understood leads to the opening of a person to the value of truth and freedom. Truth in educational activity at the academic level occupies a central place, and cannot be replaced by any other value. For both scientific research and the whole educational process, when they are not truthoriented, they lose their meaning. Therefore, all academic activity should be subordinate to it. Staying in the service of the truth is the best way to carry out educational tasks. Therefore, an academic lecturer should not only seek to discover and learn the truth, but also to disseminate it, and sometimes also to defend itespecially against widespread relativism, both epistemological and ethical. Such an attitude should be manifested with an unconditional pursuit of the truth, but also with a declassification of all its appearances, in particular falsehoods.

Living and working in the ethos of truth gives the deeds a special transparency, freeing people from assumptions and doubts, prompting them to look for something other than what they are dealing with directly. (Węgrzecki, 2004, p. 36)

In this context, lasting in the truth is also the infinite perfection of oneself and one's foster child in the constant process of upbringing. However, in order to do this, the educator himself must stand on the gunmetal ground of the truth. It is impossible to bring up yourself or others by asking Pilate's question: "What is truth?" ("Bible of the New and Old Testaments," John 18:38). If all knowledge 
was to be based on the questions themselves, who would want to acquire it? The size lies in found (and not created) answers. No one wants to sacrifice themselves to a hypothesis; to the truth-yes. Only when the teacher lives the truth is he able to convey it properly in the educational process; present it and not himself. This is manifested, among others, in the transmission of reliable information, an attitude full of trust towards the lecturer, but also the will to create by himself a generation of successors who will be able to undertake, in a responsible manner, further effort to seek and discover the truth.

The second foundation in the perspective of modern academic education appears in the form of freedom. In this context, a research and didactic worker as an educator can never take it away from his students. On the contrary, it is they who, wanting to improve themselves, will try to grow up to rational freedom, not to change it into arbitrariness or playfulness, in which it is supposed that everything is allowed. Freedom, therefore, belongs to the integral human structure that manifests itself in his operation. Hence the simple conclusion that freedom is the root of becoming a good or a bad person through one's actions. Freedom in the academic environment is indispensable in the entire scientific and didactic process. Without freedom, it is impossible to conduct research, looking for this multidimensional space of answers and analyses of problems, to pursue in accordance with your reason and conscience, thereby rejecting the pressure of negative external factors, or the self-paralysis of internal enslavement. In addition, it is the ability to speak their own courts, but also to respect other people's opinions. In this context, one must remember "educating to freedom, that is, teaching oneself to realize one's own abilities and constantly comparing one's behavior with the truth it triggers. Moral education is the teaching of freedom, [...] developing the skills of the right choice" (Ożóg, 1996, p. 127). The lecturer should, therefore, assist the student in improving cognitive abilities in reaching the truth. The measure of man's maturity and his freedom is the ability to distinguish between truth and falsehood, and the ability to develop his own judgment about the objective state of affairs (John Paul II, 1998).

\section{The role of ethics in the academic teaching process}

Education is an action aimed at improving people. Directly, improvement on a moral level is carried out on the basis of ethical actions. Therefore, since the personalistic norm concerns man as a person, and at the same time is the foundation for building personalistic ethics, it can be successfully said that "ethics [...] is for man, by man and from man" (Gałkowski, 2002, p. 20). It deals with all areas of human activity. Moreover, "it finds itself only when it becomes a proclamation about the dignity of a person" (Styczeń, 1993, p. 13). However, the question arises - how do we promote it, how do we cultivate it to have universal reference and just right of being? Its operation, in a way, has a salutary effect on man-the de- 
velopment and perfection of his humanity. It is for this reason that it will play such an important role in the whole process of academic education, especially in the context of educational activities.

We must remember that education, after all, moves along the winding recesses of axiology, realizing in some measure the vision of a human being on the way. There is no guarantee on this route of overcoming obstacles without failures. What is more, the participant of this journey is not always able to realize-both during its duration and after its end - the role of other people, himself or the configuration of various conditions, exerting a significant influence on the formation of his own, constantly evolving curriculum vitae. After all, as a learner (or perhaps most importantly-because more consciously), the human being, being homo educandus, is integrated into all kinds of axiological processes that, subject to constant changes, make him often difficult, existential choices-due to which he builds his personality.

The above facts are confirmed in the opinion of the students themselves, who indicate in their statements the need to learn about ethical principles and apply them in their lives. Research was carried out at the University of Economics in Katowice, where respondents were students of the fourth and fifth years of studies who did not participate in classes on economic ethics (they did not choose this subject as an optional lecture). In the conducted research, the selection of such a group of respondents was a deliberate procedure, because it was assumed that students who participated in lectures on ethics should have an extended state of awareness on these topics, and those who did not participate- not necessarily. ${ }^{1}$ In the group of 244 respondents, there were 186 women and 58 men, of which 75 were from the Finance and Insurance Department, 94 from the Management Department and 75 from the Faculty of Economics. ${ }^{2}$

The surveyed students were asked, inter alia, about the need to conduct reflection and discussion on ethical issues used in business activities at a university. In response to this question, over $67 \%$ of respondents (answers "yes" and "rather yes") expressed their willingness to participate in a dialogue on ethical aspects of management. They were also asked whether students of the University of Economics in Katowice should improve their knowledge of economic ethics. 90\% (answers "yes" and "rather yes") of all respondents thought that this should happen in this particular university.

\section{Conclusions}

There is a great demand in the academic environment for ethical reflection. The consequence may, in this context, be a reflection on the dissemination of knowledge in the field of professional ethics, the traditions of which date back to

\footnotetext{
${ }^{1}$ This is confirmed by research carried out among students of the University of Economics in Katowice (cf. Polok, 2007).

${ }^{2}$ In a wider version, the research that concerned Social Responsibility and the knowledge of ethical principles was published by Polok (2011).
} 
antiquity, when Hippocrates wrote the ethical principles of doctors for the first time, and Cicero those of advocates (Filek, 2004, p. 34). In today's reality, the issues of professional ethics have widened and gained great social significance. These issues no longer apply only to those professions that are traditionally considered to be particularly socially important, but almost all professional groups that already exist, as well as those that are just emerging.

One can speak of professional ethics as a set of moral norms defining the behavior of members of a given profession. It often takes the form of a code of ethics of a given professional group, in which moral standards are concluded, which are required from a person practicing a given profession. Such professional ethics can be defined as a normative ethic that describes the personal pattern of a given profession, its ethical goals, norms of conduct in practice and typical ethical conflicts that may arise in the practice of action. Professional ethics starts with the general, overarching objectives of the professional group's activity, with the aim of developing rules of conduct in specific situations, indicating what principles should be followed by the person performing the given function and what choices should be made in specific circumstances. Professional ethics wants to indicate the criteria for the right choice, especially in ethically problematic situations. These criteria are defined by: defining the duties of a given profession and determining the scope of responsibility of the person performing it.

The narrowly understood professional ethics is mainly limited to written moral norms specifying how a representative of a given profession should or should not proceed. The point of such professional ethics essentially lies in institutionalized norms, taking the form of a codex, oath or vow. More widely understood professional ethics includes moral rules regulating the cohabitation of members of a professional group with each other and in relations with external stakeholders (more on this topic, cf. Sułek \& Świniarski, 2001, p. 63 et seqq.). In this case, institutionalized moral norms are extended by unwritten rules of conduct resulting from the traditions of a given profession. Professional ethics in this approach is a community of selected values, traditions that go beyond the scope of only a duty or obligation; the representatives of a given profession shape their ethos expecting mutually determined behaviors from each other. The formalized version of professional ethics takes the form of ethical codes, the purpose of which is to list the rights of members of a given profession and to resolve conflict situations.

The above dependencies become more significant, as long as it is noted that they reflect on professional ethics and lead to the education of specific human improvements, which in turn have a considerable impact on the quality of work (Gogacz, 1998, p. 14). In other words, the introduction of classes in the field of ethics in higher education simply translates into the implementation of appropriate standards in the academic environment, thanks to which there is growing hope for improving the quality of professional activities. However, apart from the socioeconomic dimension, teaching ethics is even more important in the personal dimension. Moral improvement is, after all, the improvement of the fundamental, internal structure of human existence. In this way, the academic process of educa- 
tion, in addition to its intellectual dimension, realizes its educational goals. Personalistic ethics contribute to the improvement of man in a colossal way-both from a moral perspective and in a broader context, to various areas of social, economic, political and cultural life.

\section{References}

Adamczyk, J. (2009). Społeczna odpowiedzialność przedsiębiorstw. Warszawa: Państwowe Wydawnictwo Ekonomiczne.

Anzenbacher, A. (1992). Wprowadzenie do filozofii. Kraków: WAM.

Bible of the New and Old Testaments. (1980). Poznań-Warszawa.

Dylus, A. (1984). Sprawozdanie z konferencji etyczno-psychologicznej (Jabłonna 14.03.1983.) "Pojęcie godności w etyce i psychologii”. Studia Philosophiae Christianae, 20(1), 215-220.

European Commission. (1995). White Paper on Education and Training. Teaching and Learning - Towards the Learning Society [Biała Księga Kształcenia i doskonalenia. Nauczanie i uczenie się. Na drodze uczącego się społeczeństwa]. https://publica tions.europa.eu/en/publication-detail/-/publication/d0a8aa7a-5311-4eee-904c-98fa54 $1108 \mathrm{~d} 8 /$ language-en

Filek, J. (2004). Rola etyki w działalności samorządowej. In J. Filek (Ed.), Etyczne aspekty działalności samorządu terytorialnego (pp. 19-53). Kraków: Małopolska Szkoła Administracji Publicznej Akademii Ekonomicznej w Krakowie. http://www.msap. uek.krakow.pl/doki/publ/pri_etyka-p.pdf

Gałkowski, J. W. (2002). Zasady etyki zawodowej - etyka biznesu. In M. Borkowska, \& J. W. Gałkowski (Eds.), Etyka w biznesie. Lublin: Towarzystwo Naukowe Katolickiego Uniwersytetu Lubelskiego.

Gogacz, M. (1998). Czym jest etyka zawodowa? In A. Andrzejuk (Ed.), Zagadnienie etyki zawodowej. Warszawa: Oficyna Wydawnicza Navo.

Jaroszyński, P. (1992). Przedmowa. In M. A. Krąpiec, S. Kamiński, Z. J. Zdybicka, \& P. Jaroszyński, Wprowadzenie do filozofii (pp. 5-10). Lublin: Katolicki Uniwersytet Lubelski.

Jaskot, K. W., \& Murawska, A. (2006). Charakterystyka "wieku studiów”. Konsekwencje pedagogiczne. In K. W. Jaskot (Ed.), Wprowadzenie do pedagogiki szkoły wyższej (pp. 109-115). Szczecin: In Plus.

John Paul II. (1998). Fides et ratio. Kraków.

Kapias, M. (2009). Humanizująca rola edukacji w procesie doskonalenia człowieka na kierunku finanse i rachunkowość. In A. Kopiński (Ed.), Dydaktyka finansów na kierunku finanse $i$ rachunkowość. Materiały konferencyjne Uniwersytetu Ekonomicznego we Wrocławiu. Wrocław: Wydawnictwo Uniwersytetu Ekonomicznego.

Kapias, M., \& Polok, G. (2012). Edukacja etyczna jako fundamentalny element wychowania w środowisku akademickim. Annales. Ethics in Economic Life, 15, 193-203.

Maritain, J. (1949). Pour une philosophie de l'éducation. Paris. 
Moratis, L., Hoff, J., \& Reul, B. (2006). A dual challenge facing management education: simulation-based learning and learning about CSR. Journal of Management Development, 25(3), 213-231.

Ożóg, T. (1996). J. Maritain - przedstawiciel personalizmu w wychowaniu. In T. Kukołowicz (Ed.), Teoria wychowania. Wybrane zagadnienia. Stalowa Wola: Oficyna Wydawnicza Fundacji Uniwersyteckiej.

Polok, G. (2007). Wykłady z etyki gospodarczej elementem kształtowania postaw przedsiębiorczych studentów Akademii Ekonomicznej w Katowicach - raport z badań własnych. In P. Wachowiak, M. Dąbrowski, \& B. Majewski (Eds.), Ksztattowanie postaw przedsiębiorczych a edukacja ekonomiczna (pp. 108-113). Warszawa: Fundacja Promocji i Akredytacji Kierunków Ekonomicznych.

Polok, G. (2011). Rola wyższej szkoły ekonomicznej w propagowaniu wiedzy o społecznej odpowiedzialności biznesu. Studia Ekonomiczne, 64, 185-205.

Sobczak, A., Debucquet, G., \& Havard, Ch. (2006). The impact of higher education on students' and young managers' perception of companies and CSR: An Exploratory Analysis. Corporate Governance, 6(4), 463-475.

Styczeń, T. (1983). ABC etyki. Lublin: Wydawnictwo Katolickiego Uniwersytetu Lubelskiego.

Styczeń, T. (1993). Wprowadzenie do etyki. Lublin: Towarzystwo Naukowe Katolickiego Uniwersytetu Lubelskiego.

Sułek, M., \& Świniarski, J. (2001). Etyka jako filozofia dobrego działania zawodowego. Warsaw: Dom Wydawniczy Bellona.

Ślipko, T. (1974). Zarys etyki ogólnej. Kraków: WAM.

Węgrzecki, A. (2004). Sylwetka aksjologiczna nauczyciela akademickiego. In K. Kloc, \& E. Chmielecka (Eds.), Dobre obyczaje W kształceniu akademickim. Warszawa: Fundacja Promocji i Akredytacji Kierunków Ekonomicznych.

Wojtyła, K. (1986). Miłość i odpowiedzialność. Lublin: Towarzystwo Naukowe Katolickiego Uniwersytetu Lubelskiego.

Wojtyła, K. (1994). Osoba i czyn. Lublin: Towarzystwo Naukowe Katolickiego Uniwersytetu Lubelskiego.

Wojtyła, K. (1995). Elementarz etyczny. Wrocław: Wydawnictwo TUM.

Wójcicka, M. (2007). Wartości akademickie i rynek. Na styku rynku i wartości uprawomocnionych w instytucji akademickiej. In A. Sowińska (Ed.), Wiedza i Mądrość w edukacji akademickiej (pp. 41-56). Szczecin: Wydawnictwo Zapol. 